\title{
Bio-composite materials: a short review of recent trends, mechanical and chemical properties, and applications
}

\author{
Şafak Yıldızhan 1* , Ahmet Çalık², Mustafa Özcanlı ${ }^{3}$, Hasan Serin ${ }^{4}$ \\ 'Department of Automotive Engineering, Çukurova University, Turkey; yildizhans@cu.edu.tr, ORCID: 0000-0002-8981-9869 \\ 2Department of Mechanical Engineering, Adana Science and Technology University, Turkey; acalik@gmail.com \\ ${ }^{3}$ Department of Automotive Engineering, Çukurova University, Turkey; ozcanli@cu.edu.tr \\ ${ }^{4}$ Department of Automotive Engineering, Çukurova University, Turkey; hserin@cu.edu.tr
}

\begin{abstract}
Recently, the attraction on the bio-composite (known as green composites) materials has significantly increased due to the potential of being substitute to conventional materials used in manufacturing industries. Biocomposite materials are produced with natural fibers or natural resins instead of synthesized fibres (carbon, glass, etc fibers) or resins (poly vinyl alcohol, epoxy, etc resins ). The bio-based fibers such as jute, sisal, flax, hemp, bamboo, hair, wool, silk etc., are obtained from plants or animals. Also, natural matrix materials such as natural rubber, polyester, etc., are produced from plants. The advantages of bio-composites such as the ease of disposal and being able to composted characteristics of bio-composites after the expiration date which is not generally possible with conventional synthetic materials, being renewable, sustainable have attracted many researcher. Furthermore, the comparable mechanical properties of bio-composites make feasible for application to many different products. This study reviews the, recent trends, mechanical and chemical properties, and application of bio-composites in recent years.
\end{abstract}

Keywords: Composites, Bio-composites, Natural fibers, Review

\section{INTRODUCTION}

Bio-based composites are promising materials for future applications of automotive industry. The challenge of making automotive products lighter, safer and cheaper leads to investigate advanced materials with desired properties. Also, awareness of environmental issues forces the researchers and manufacturers to spend effort on composite and bio-composite materials field.

Composite material is a combination of two different materials with discrete properties and generally, is produced with the reinforcement of a matrix structure. The most common matrix materials are thermoset or thermoplastic resins such as polyester, epoxy and vinyl ester. And, the most common reinforcement agents are carbon, aramid and glass fibers. Composite materials also may contain additives, core materials or fillers, and have different properties than conventional materials that are used to manufacture. The main difference is the being anisotropic which means properties change with direction of the applied load. The main advantage of the composite materials is the allowance to modify the properties according to design requirements. Composite materials can be produced lighter and safer compared to its traditional counterparts.

*Corresponding authour

Email: syildizhan@cu.edu.tr
Composite materials are generally produced with fiber reinforcements and the most common reinforcement agent is carbon. Recently, many researchers focused on the natural fibers in order to produce sustainable materials for manufacturing industry. Many researchers investigated the mechanical chemical properties of the materials which are produced with natural fibers such as kenaf, abaca, grass, hemp, flax, bamboo, sisal, etc.

Recently, the all world faced with environmental concerns and issues such as sustainability and cost. Thus, researches in the field of manufacturing have focused on biomaterial technology which has promising opportunities. The ease of disposal and being able to composted characteristics of bio-composites after the expiration date which is not generally possible with conventional synthetic materials have attracted many researcher. Also, the advantages of natural fibers such as low weight, corrosion resistance, and high strength compared to synthetic counterparts make bio-fibers more attractive. But also, the bio-fibers have some drawbacks such as being anistropic and extra moisture absorption.

The final characteristics of the composite materials are 
determined by many factors such as matrix material, fibre, fibre direction, fibre application type, production method, and etc. Matrix material is an important parameter for mechanical and chemical features of the composite material product and most of the matrix materials are petro-chemical based materials. Depletion of fossil sources is a critical issue for composites. Therefore, some researchers are studying on the natural resins which are obtained from plants in order to synthesize matrix material for composite-materials.

The increasing attraction and importance of the bio-composites increased the number of publications on that particular subject with a variety of different perspectives. The publications including books, articles and reviews show the importance of the subject. John and Thomas (2008), Faruk et al. (2012), Hassan et al. (2010), Shinoja et al. (2011), Venkateshwaran and Elayaperumal (2010), reviewed bio-composite materials produced with natural fiber and matrices [1-5]. This paper includes the recent studies on the subject of bio-composites, focusing on the sources for natural fibers excluding animal (hair, silk, wool, etc) based fibers and matrices, production methods, mechanical and chemical properties of bio-composites and application of the bio-composite materials.

\section{FIBERS}

Fibers are the reinforcing agents of the composite materials and main part of the composite system that carries structural loads. Composite materials are mostly produced with synthetic reinforcing agents. Generally, carbon, aramid and glass fibers are used for composite material production. But, the sustainability and environmental issues need effective solutions for the mankind. The efforts on producing renewable and biodegradable materials for manufacturing industry are widening all around world.

Fibers can be divided into two main categories as natural and synthetic. Synthetic fibers are generally petro-chemical products. Natural fibers are obtained from plants or animals. Plant based fibers are composed of cellulose and animal fibers includes proteins (hair, silk, wool, etc.). Plant fibers consist of leaf, seed, bast, fruit, wood, grass, and stalk. In this study, plant fiber sources were reviewed and the results were given in following sections.

\subsection{Plant Fibers (Lignocellulosic Fibers)}

Plant fibers are promising reinforcement agents mainly composed of cellulose and, with the concerns of sustainability and renewability these fibers are getting more attention by the researchers and the industry.

Lignocellulosic fibers are formed basically from three chemical substances. These substances are cellulose (a-cellulose), hemicelluloses and lignin. Also, lignocellulosic fibers may contain other different substances depending on the plant, region, species, etc., such as waxes, pectin, inorganics, starch, protein, etc. Table 1 shows the chemical composition of the plant based natural fibers. Even though the all plant fibers are basically polymers of sugar, the chemical composition varies with many parameters such as climate, soil type, environmental factors, etc.

Table 1. Chemical compositions of some natural fiber types

\begin{tabular}{|c|c|c|c|c|c|}
\hline Type & Fiber & $\begin{array}{c}\text { Cellulose } \\
(w t \%)\end{array}$ & $\begin{array}{c}\text { Hemicellulose } \\
\text { (wt\%) }\end{array}$ & $\begin{array}{l}\text { Lignin } \\
(w t \%)\end{array}$ & Reference \\
\hline \multirow[t]{4}{*}{ GRASS } & Bagasse & 44,1 & 31,8 & 22,3 & {$[6]$} \\
\hline & Bamboo & $22,8-56,7$ & $17,2-43,8$ & $1,1-26,6$ & [7] \\
\hline & Canary & $37,2-41,7$ & $19-22,9$ & - & {$[8]$} \\
\hline & Corn & 41,7 & 46 & 7,4 & [9] \\
\hline \multirow[t]{2}{*}{ WOOD } & Hard Wood & $31-64$ & $25-40$ & $14-34$ & [10] \\
\hline & Soft Wood & $30-60$ & $20-30$ & $21-37$ & [10] \\
\hline \multirow[t]{3}{*}{ FRUIT } & Coir & $36-43$ & $0,15-0,25$ & $41-45$ & {$[11]$} \\
\hline & Kapok & 35 & 22 & 21,5 & [12] \\
\hline & Oil palm & 47,91 & 19,06 & 24,45 & [13] \\
\hline \multirow{8}{*}{$\begin{array}{c}\text { BAST } \\
\text { (STEM) }\end{array}$} & Jute & $61-71,5$ & $13,6-20,4$ & $12-13$ & {$[11]$} \\
\hline & Flax & 74,93 & 10,37 & 2,62 & [14] \\
\hline & Hemp & 75 & 15 & 3 & {$[15]$} \\
\hline & Kenaf & $31-57$ & $21,5-23$ & $15-19$ & [16] \\
\hline & Kudzu & 33 & 11,3 & 14 & [17] \\
\hline & Nettle & $79-83,6$ & $6,5-12,5$ & $3,5-4,4$ & {$[18]$} \\
\hline & Ramie & $61,85-73,21$ & $5,27-7,58$ & $4,6-, 9,06$ & [19] \\
\hline & Roselle & 70,20 & 7,21 & 14,91 & [20] \\
\hline \multirow[t]{5}{*}{ LEAF } & Abaca & 60,4 & 20,8 & 12,4 & {$[21],[22]$} \\
\hline & Banana & $63-64$ & $10-24$ & 5 & {$[23]$} \\
\hline & Henequen & $70-77,6$ & $4--20$ & $8-13,1$ & {$[22],[24]$} \\
\hline & Pineapple & $70-82$ & 18 & $5-12$ & {$[25]$} \\
\hline & Sisal & 26 & 38,2 & 26 & [26] \\
\hline \multirow[t]{2}{*}{ SEED } & Cotton & $82,7-92$ & $5,7-6$ & 0 & [22] \\
\hline & Kapok & 64 & 13 & 23 & [27] \\
\hline \multirow[t]{2}{*}{ STALK } & Wheat & $33-38$ & $26-32$ & $17-19$ & {$[25]$} \\
\hline & Rice & $28-36$ & $23-28$ & $12-14$ & [25] \\
\hline
\end{tabular}

\section{Cellulose}

Cellulose is the main structural components of the natural fibers which consist of D-glucopyranose units joined each other with 1,4-b-D-glycosidic bonds (C1 and C4). Cellulose is hydrophilic and has around 10000 degree of polymerization which varies with fiber type. The hydrogen bonds provided by hydroxyl $(\mathrm{OH})$ in the structure and also van der Waals forces makes cellulose molecules to be crystalline packed. This mainly determines the physical properties of celluloses. Besides these highly ordered regions, cellulose has less ordered amorphous regions. In the nature, two types of cellulose which are cellulose $\mathrm{I}_{\alpha}$ and $\mathrm{I}_{\beta}$ exist $[1,22]$. Cellulose can be degraded with chemical applications, but also is resistant to oxidising and alkali agents and hydrolysis relatively.

\section{Hemicellulose}

Hemicellulose is the second major structural component of the fibers. It is not a type of cellulose and has more complex structure than natural cellulose. Hemicelluloses are composed of different sugar units, very hydrophilic, non-crystalline, and acts as the matrix for cellulose microfibrils. Hemi- 


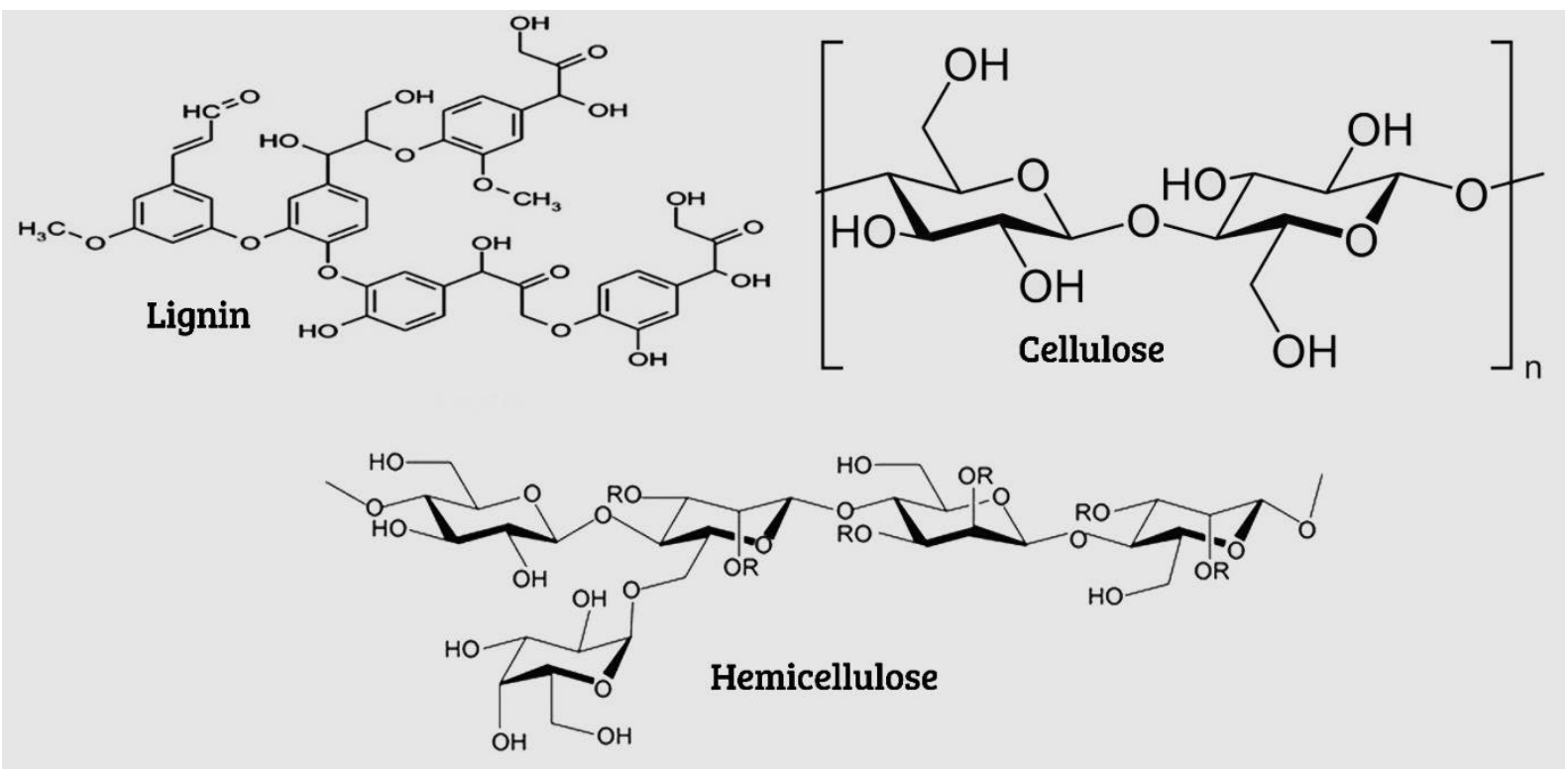

Figure 1. Structure of cellulose, hemicellulose and lignin.

celluloses have a degree of polymerization around 50-300. Hemicelluloses can be soluted in alkali and hydrolyzed in acids [28].

\section{Lignin}

Lignin is the hydrophobic, insoluble in the water, amorphous aromatic polymer resulting from the oxidative combinatorial coupling of 4-hydroxyphenylpropanoids which has strong intramolecular bonds. Lignin is especially presented in vascular plants and acts as filler between cellulose hemicellulose and pectin structures. Lignin provides stiffness to cellulose and hemicellulose structures. Figure 1 depicts the chemical structure of the cellulose, hemicellulose and lignin molecules [1, 22, 28].

Some of the most important fiber sources and the recent studies were reviewed and the important mechanical properties such as tensile strength, elastic modulus, and elongation at break were given in Table 2 .

\subsubsection{Grass}

\section{Bagasse}

Bagasse also known as sugarcane bagasse is the waste (by-product) of sugar production. While paper is produced from bagasse in some Latin American countries, also bagasse can be used to produce animal feed, furfural, and biodegradable composite materials [29].

\section{Bamboo}

Bamboo which is mostly grown in Asia is a member of grass family and there are above 1400 types. Bamboo stem is hard and woody. The bamboo fibers are produced from pulp of bamboo plants. It has wide application area such as food, paper, textile, furniture, construction, and in most of the woody goods. Bamboo fibers can provide fine mechanical strength, stiffness, low density and high modulus [30, 31].

\section{Corn}

Corn is one of the major plants used in food industry all around the world. The high amounts of corn production and processing ends up with different by-products such as corn husk and corncob. The fibrous structure of these by-products makes corn promising candidate for bio-composite production [32].

\subsubsection{Wood}

Woods are categorized according to their botanical properties. The angiosperm woods are called hard and gymnosperm woods are soft. The main anatomical difference is the enclosement of the seeds in the ovary of the flower. Both hardwoods and softwoods can be used as reinforcement material or filler $[22,33]$.

\section{Hard Wood}

Hardwoods contain vessels and are porous and most of the tropical woods are hardwoods. Alder red Ash, Oregon, Aspen, Birch, paper Cottonwood, Oak, Beech, and Maple are the examples of the hardwoods.

\section{Soft Wood}

Softwoods do not contain vessels and are non-porous. Cedar, Western Red, Cedar, Larch, and Pine are the examples of softwoods.

\subsubsection{Fruit}

\section{Coir}

Coir is a by-product of different coconut products. Coir contains a high amount of lignin (41-45\%) compared to other natural fibers [11]. The lignin is generally extracted with a chemical or organic solvent. Annually, over 50 billion coconuts are harvested and a very small amount of coconut husk is recycled (around 15\%) [34]. Thus, coir husk fibers have a great potential for bio-composite reinforcement material production.

\section{Kapok}

Kapok fibers are produced from natively tropical tree kapok 
which can grow up to 50 meters. Kapok products have different applications like pillow filling from kapok cotton and oil extraction from its seeds. The high amounts of kapok harvesting produce a potential for recycling the wastes and by-products of the kapok [35, 36].

\section{Oil Palm}

Oil palm is an important crop mostly harvested in Malaysia and Indonesia and generally used for palm oil extraction and paper production. The great amount of oil palm production also ends up with a high amount of biomass including empty fruit bunches, fronds and trunks [37].

\subsubsection{Bast (Stem)}

\section{Jute}

Jute which has highest production volume for fibers after cotton all around the world is mostly cultivated for its fiber. It mainly grows in India and Bangladesh [38]. Also, China, Nepal, Brazil and Thailand are the some other countries that cultivate jute fiber. Despite the disadvantages of the jute fiber such as being highly brittle and relatively lower tensile strength it has a broad range of application due to fine texture and heat resistance [39] .

\section{Flax}

Flax is one of the known oldest textile raw material and cultivated for centuries. Linen fabric is produced from flax plant and due to its high strength has a wide application area. Flax fibers are used for production of tents, canvas, towel, sails furnishing fabrics, household textiles etc [40].

\section{Hemp}

Hemp is another important crop used in fiber reinforcement and the history of hemp usage is very old. Even though the bad reputation about the hemp (narcotic issues), industrial hemp can't be used as narcotic since it produces 9- tetrahydrocannabinol (THC) less than $0.2 \%$ [41]. Hemp is an annual crop which has significant growth rate and suitable for temperature climates [2].

\section{Kenaf}

Kenaf has a high potential to be the reinforcement material for bio-composite production due to its growth rate, and similar structure to jute and cotton which are the mostly used crop for fiber production [42]. Kenaf is an annual crop and its origin is Africa. It is cultivated mostly in Africa, Bangladesh, India, China and Malaysia [43].

\section{Kudzu}

Kudzu is an invasive crop native to southern regions of Japan and China. It is mostly used for erosion control. It is used for clothing and basketry for centuries. It has a similar morphology to flax and hemp [17] and thus it has potential to be the reinforcement material for bio-composite production.

\section{Nettle}

Nettle also known as stinging nettle is a perennial crop which has similar properties to flax. There are several species of the nettle crop.

\section{Ramie}

Ramie also known as Chinese nettle is a perennial crop that grows in warm climates. The treatment of ramie fibers is expensive due to gummy resins in the structure. Ramie is generally used for clothing but recently it has been started to use in automotive industry. Ramie fibers have long length and lower density than glass fibers [44].

\section{Roselle}

Roselle is a crop that is cultivated for its jute-like fibers mostly in tropical regions. Its origin is assumed as Africa. It is an annual crop and can grow up to $2.5 \mathrm{~m}$ [45].

\subsubsection{Leaf}

\section{Abaca}

Abaca is one the of most important leaf fibers. Abaca is mostly cultivated in where its origin is Philippines. It is related with banana family. Abaca fibers have good mechanical properties like high strength and flexibility [46].

\section{Banana}

Banana is a tropical plant mostly cultivated for its nutritious fruit. Its tree bark have good mechanical properties which can be used as reinforcement agent instead of synthetic ones [47].

\section{Henequen}

Henequen plant natively grows in Guatemala and Mexico. It is cultivated for its fibers in order to made ropes mostly. It has similar properties to sisal and also called Cuban or Yucatan sisal [48].

\section{Pineapple}

The pineapple which origin is Brazil now spreaded to all tropical regions. It has a very high amount of production and thus it provides a great potential for fiber production as by-product.

\section{Sisal}

Sisal is native to Mexico and mostly cultivated in Brazil. It has wide range of application area. The sisal fibers possess good mechanical properties and thus it is used in bio-composite material production [49].

\subsubsection{Seed}

\section{Cotton}

Cotton is one of the most important crops that used all over the world. It has variety of uses. But due to its relatively low mechanical properties it rarely used as reinforcement agent. It is generally used as secondary fiber in green hybrid-composites. 


\begin{tabular}{|c|c|c|c|c|c|}
\hline Type & Fiber & $\begin{array}{l}\text { Density } \\
\left(\mathrm{g} / \mathrm{cm}^{3}\right)\end{array}$ & $\begin{array}{c}\text { Tensile } \\
\text { Strength } \\
(\mathrm{MPa})\end{array}$ & $\begin{array}{c}\text { Elastic } \\
\text { Modulus } \\
(\mathrm{GPa})\end{array}$ & $\begin{array}{l}\text { Elongation } \\
\text { at Break } \\
(\%)\end{array}$ \\
\hline \multirow[t]{2}{*}{ GRASS } & Bagasse & $1.2-1.25$ & $20-290$ & $17-27.1$ & 1.1 \\
\hline & Bamboo & $0.6-11$ & $140-230$ & $11-17$ & - \\
\hline \multirow[t]{2}{*}{ WOOD } & $\begin{array}{l}\text { Hard } \\
\text { Wood }\end{array}$ & $0.3-0.88$ & $51-210.7$ & $5.2-15.6$ & - \\
\hline & Soft Wood & $0.3-1.5$ & $45.5-1000$ & $3.6-40.0$ & 4.4 \\
\hline \multirow[t]{2}{*}{ FRUIT } & Coir & $1.15-1.45$ & $106-593$ & $1.27-6.0$ & $15.0-59.9$ \\
\hline & Oil palm & $0.7-1.55$ & $100-400$ & $1.0-9.0$ & $8-25$ \\
\hline \multirow{7}{*}{$\begin{array}{l}\text { BAST } \\
\text { (STEM) }\end{array}$} & Jute & $1.3-1.46$ & $393-800$ & $10-30$ & $1.5-10.0$ \\
\hline & Flax & $1.4-1.5$ & $345-1500$ & $27.6-80$ & $1.2-3.2$ \\
\hline & Hemp & $1.47-1.48$ & $550-900$ & 70 & $1.6-4.0$ \\
\hline & Kenaf & $1.2-1.45$ & $295-930$ & 53 & $1.6-6.9$ \\
\hline & Kudzu & - & $130-418$ & - & - \\
\hline & Nettle & & 650 & 38 & 1.7 \\
\hline & Ramie & $1.45-1.5$ & $220-938$ & $24.5-128$ & $1.2-3.8$ \\
\hline \multirow[t]{5}{*}{ LEAF } & Abaca & 1.5 & $400-980$ & $3-12$ & $3-10$ \\
\hline & Banana & 1.35 & $355-500$ & $12-33.8$ & $5.9-53$ \\
\hline & Henequen & $1.2-1.4$ & $430-580$ & $10.1-16.3$ & $3.0-4.7$ \\
\hline & Pineapple & $0.8-1.6$ & $170-1672$ & 82 & $1.0-3.0$ \\
\hline & Sisal & $1.33-1.5$ & $400-700$ & $9.0-38.0$ & $2.0-14$ \\
\hline \multirow[t]{2}{*}{ SEED } & Cotton & $1.5-1.6$ & $287-597$ & $5.5-12.6$ & $3.0-10.0$ \\
\hline & Kapok & 0.38 & 93.3 & - & - \\
\hline \multirow[t]{4}{*}{ SYNTHETIC } & Carbon & 1.4 & 4000 & $23-240$ & $1.4-1.8$ \\
\hline & E-glass & 2.5 & $2000-3500$ & 70.0 & $0.5-3.0$ \\
\hline & $\mathrm{S}$-glass & 2.5 & 4570 & 86.0 & 2.8 \\
\hline & Aramide & 1.4 & $3000-3150$ & $63-70$ & $2.5-3.7$ \\
\hline
\end{tabular}

\section{Kapok}

Kapok has similar properties to cotton and mostly cultivated in Malaysia. Kapok husk which is the by-product of the kapok production can be used as the fiber production raw material [36].

Using bio-fibers has some cons as well as pros. The main drawbacks of bio-fibers are the high moisture absorption, relatively lower structural strength and poor adhesion with matrix material. Thus, many researchers studied on morphological properties and the treatments for modifications of bio fibers $[6,14,16,24,44,46,50-94]$. Also many articles have been published that reviews the treatment methods and the effects of these treatments on mechanical, chemical and morphological properties of bio-fibers and bio-composites [55, 95-97]. The main goal for all treatment types (physical, chemical or physico-chemical) is to improve the adhesion characteristics of the fibers and by this way to improve the mechanical properties of the bio-composites. The most common physical methods are simple mechanical methods (stretching, calendaring, rolling), solvent extraction, electric discharge (corona, plasma, ionized air), thermal treatments. Alkaline, coupling (silane, acylation, graft copolymerization), bleaching (reduction, oxidation), enzyme, peroxide treatments are the chemical methods for modification of the fibers. Also there are some methods that combine the physical and chemical methods and called pyhsico-chemical

Table 3. Mechanical properties of some natural fiber reinforced composite materials

\begin{tabular}{|c|c|c|c|c|c|c|c|c|}
\hline Fiber & $\begin{array}{c}\text { Fiber Treat- } \\
\text { ment }\end{array}$ & Matrix & $\begin{array}{l}\text { Fibre/Matrix- } \\
\text { Ratio (\%-wt - } \\
\text { Fiber/Matrix) }\end{array}$ & $\begin{array}{l}\text { Tensile Stren- } \\
\text { gth (MPa) }\end{array}$ & $\begin{array}{l}\text { Elastic Mo- } \\
\text { dulus (GPa) }\end{array}$ & $\begin{array}{c}\text { Elongation at } \\
\text { Break (\%) }\end{array}$ & Production Method & Reference \\
\hline Bagasse & Untreated & $\begin{array}{c}\text { Cardanol-formal- } \\
\text { dehyde }\end{array}$ & 15 & 24.4 & 1.8 & - & $\begin{array}{l}\text { Compression } \\
\text { Moulding }\end{array}$ & {$[105]$} \\
\hline \multirow{2}{*}{$\begin{array}{l}\text { Bagasse } \\
\text { powder }\end{array}$} & Untreated & \multirow[t]{2}{*}{ Polypropylene } & 3 & 35 & 2.0 & \multirow[t]{2}{*}{ - } & \multirow[t]{2}{*}{ Injection Molding } & \multirow[t]{2}{*}[106]{} \\
\hline & ChOAc & & 3 & 40 & 2.6 & & & \\
\hline \multirow[t]{2}{*}{ Bagasse } & Untreated & \multirow[t]{2}{*}{ Polyethylene } & \multirow[t]{2}{*}{5} & $36 \pm 5.1$ & $330 \pm 8.4$ & $8.7 \pm 5.1$ & \multirow[t]{2}{*}{ Melt Compounding } & \multirow[t]{2}{*}{ [107] } \\
\hline & Mechanical & & & $129 \pm 1.1$ & $440 \pm 6.1$ & $10.6 \pm 5.1$ & & \\
\hline \multirow[t]{2}{*}{ Bamboo } & Untreated & \multirow[t]{2}{*}{ Polypropylene } & \multirow[t]{2}{*}{$80 / 20$} & 37 & 4.34 & \multirow[t]{2}{*}{-} & \multirow{2}{*}{$\begin{array}{l}\text { Compression } \\
\text { Molding }\end{array}$} & \multirow[t]{2}{*}[108]{} \\
\hline & Alkali & & & $40-51$ & $4.38-5.57$ & & & \\
\hline \multirow[t]{3}{*}{ Corn } & Untreated & \multirow[t]{3}{*}{ Polylactic Acid } & \multirow[t]{3}{*}{ - } & 46 & \multirow[t]{3}{*}{-} & \multirow[t]{3}{*}{ - } & \multirow[t]{3}{*}{ Injection Molding } & \multirow[t]{3}{*}{ [109] } \\
\hline & Alkali & & & $58-64$ & & & & \\
\hline & Alkali+Silane & & & $62-72$ & & & & \\
\hline \multirow[t]{3}{*}{ Kapok } & \multirow[t]{3}{*}{ Untreated } & \multirow[t]{3}{*}{ Cassava Starch } & 5 & 3 & 25 & 30 & \multirow{3}{*}{$\begin{array}{l}\text { Compression } \\
\text { Molding }\end{array}$} & \multirow[t]{3}{*}[110]{} \\
\hline & & & 10 & 4 & 40 & 20 & & \\
\hline & & & 15 & 4.5 & 40 & 19 & & \\
\hline \multirow[t]{2}{*}{ Jute } & $\mathrm{NaOH}$ & \multirow[t]{2}{*}{ Polyethylene } & \multirow[t]{2}{*}{30} & $10.9 \pm 0.1$ & $0.25 \pm 0.02$ & $12.8 \pm 0.9$ & \multirow[t]{2}{*}{ Injection Moulding } & [111] \\
\hline & Stearic Acid & & & $12.8 \pm 0.3$ & $0.26 \pm 0.01$ & $11.8 \pm 0.8$ & & \\
\hline Flax & - & Polypropylene & 30 & $29 \pm 1.5$ & $5 \pm 0.4$ & $2.7 \pm 1.5$ & Compression & [112] \\
\hline & & & 40 & $29 \pm 0.8$ & $7.6 \pm 0.9$ & $1.5 \pm 0.8$ & Moulding & \\
\hline & & Polylactic Acid & 30 & $53 \pm 0.2$ & $8.3 \pm 0.6$ & $1.0 \pm 0.2$ & & \\
\hline & & & 40 & $44 \pm 0.2$ & $7.3 \pm 0.5$ & $0.9 \pm 0.2$ & & \\
\hline Kenaf & - & Polylactic Acid & 10 & $61.1 \pm 1.3$ & $3.8 \pm 0.1$ & - & Injection Molding & [113] \\
\hline & & & 20 & $74.5 \pm 0.9$ & $5.3 \pm 0.2$ & & & \\
\hline Sisal & - & Thermoplastic & 5 & 3.8 & 0.205 & 5.3 & Twin Screw Ext- & {$[114]$} \\
\hline & & caprolactone. & 10 & 3.6 & 0.255 & 2.9 & & \\
\hline Cotton & Untreated & Epoxy & - & 35 & - & - & Hand Lay-Up & {$[115]$} \\
\hline & Alkali & & & 45 & & & & \\
\hline
\end{tabular}


methods such as hydrothermal and steam explosion $[10,16$, 22, 98-104].

\section{BIO-COMPOSITES MECHANICAL PROPERTIES}

While the fibers carry the structural loads of the composite parts matrix material keeps the structure in solid phase that forms the shape and the appearance of the product. Today, most of the products produced from composite material include non-renewable matrices of petroleum based chemicals. But, there are numerous studies that investigate the usage of renewable and sustainable matrices for composite material production. The most commonly used thermoplastic composites for bio-composite material production are polystyrene (PS), polyethylene (PE), polypropylene (PP), and polyvinylchloride (PVC). Epoxy, vinyl esters, polyester and phenol formaldehyde are the thermoset resins which are used to produce composite materials reinforced with natural fibers [2]. Mechanical properties of the final material depend on many different parameters. The main parameters are the fiber and matrix material properties and the compatibility of matrix and the fiber bundle. Mechanical properties of different matrices and fibers were studied by many researchers and a brief summary of the studies were given Table 3.

\section{CONCLUSIONS}

This paper is a brief review study of the recent investigations on mechanical and chemical properties and applications of bio-fibers and bio-composites. The study showed that bio-composites are promising materials for the future applications in many industrial sectors especially in automotive sector which is the leading sector of the industrial and technological development. The remarkable advantages such as the renewability and sustainability and further being bio-degradable characteristics of bio-composite materials make bio-composites the "future materials". Also studies show that, the issues of bio-composites such as moisture absorption and low adhesion characteristics are need to be solved in order to replace conventional materials or synthetic composites. Reinforcing synthetic matrix with natural fibers could be a temporary solution for the progress. But, it is mandatory to use both natural fibers and natural resins to produce goods from completely recyclable, bio-degradable, "green" materials. The increasing awareness of the people and the legislations will enforce the usage of bio-composite materials instead of conventional materials to ensure the sustainability.

\section{ACKNOWLEDGEMENT}

The authors would like to thank the Cukurova University Scientific Research Project Coordination (FBA-2017-9122) for financial support to this project.

\section{REFERENCES}

[1] John, M., Thomas, S., (2008). Biofibres and biocomposites. Carbohydrate Polymers 71(3): 343-64, Doi: 10.1016/j.carbpol.2007.05.040.
[2] Faruk, O., Bledzki, A.K., Fink, H.-P., Sain, M., (2012). Biocomposites reinforced with natural fibers: 2000-2010. Progress in Polymer Science 37(11): 1552-96, Doi: 10.1016/j.progpolymsci.2012.04.003.

[3] Hassan, A., Salema, A.A., Ani, F.N., Bakar, A.A., (2010). A review on oil palm empty fruit bunch fiber-reinforced polymer composite materials. Polymer Composites 31(12): 2079-101, Doi: 10.1002/pc.21006.

[4] Shinoj, S., Visvanathan, R., Panigrahi, S., Kochubabu, M., (2011). Oil palm fiber (OPF) and its composites: A review. Industrial Crops and Products 33(1): 7-22, Doi: 10.1016/j.indcrop.2010.09.009.

[5] Venkateshwaran, N., Elayaperumal, A., (2010). Banana Fiber Reinforced Polymer Composites - A Review. Journal of Reinforced Plastics and Composites 29(15): 2387-96, Doi: 10.1177/0731684409360578.

[6] Santucci, B.S., Bras, J., Belgacem, M.N., Curvelo, A.A. da S., Pimenta, M.T.B., (2016). Evaluation of the effects of chemical composition and refining treatments on the properties of nanofibrillated cellulose films from sugarcane bagasse. Industrial Crops and Products 91: 238-48, Doi: 10.1016/j.indcrop.2016.07.017.

[7] Yang, Z., Li, K., Zhang, M., Xin, D., Zhang, J., (2016). Rapid determination of chemical composition and classification of bamboo fractions using visible-near infrared spectroscopy coupled with multivariate data analysis. Biotechnology for Biofuels 9(1): 35, Doi: 10.1186/s13068-0160443-z.

[8] Butkutè, B., Lemežienė, N., Kanapeckas, J., Navickas, K., Dabkevičius, Z., Venslauskas, K., (2014). Cocksfoot, tall fescue and reed canary grass: Dry matter yield, chemical composition and biomass convertibility to methane. Biomass and Bioenergy 66: 1-11, Doi: 10.1016/j.biombioe.2014.03.014

[9] Yeng, C.M., Husseinsyah, S., Ting, S.S., (2015). A comparative study of different crosslinking agent-modified chitosan/corn cob biocomposite films. Polymer Bulletin 72(4): 791-808, Doi: 10.1007/s00289-015-1305-8.

[10] Jawaid, M., Abdul Khalil, H.P.S., (2011). Cellulosic/synthetic fibre reinforced polymer hybrid composites: A review. Carbohydrate Polymers 86(1): 1-18, Doi: 10.1016/j.carbpol.2011.04.043.

[11] Gurunathan, T., Mohanty, S., Nayak, S.K., (2015). A review of the recent developments in biocomposites based on natural fibres and their application perspectives. Composites Part A: Applied Science and Manufacturing 77: 1-25, Doi: 10.1016/j.compositesa.2015.06.007.

[12] Hori, K., Flavier, M.E., Kuga, S., Lam, T.B.T., liyama, K., (2000). Excellent oil absorbent kapok [Ceiba pentandra (L.) Gaertn.] fiber: fiber structure, chemical characteristics, and application. Journal of Wood Science 46(5): 401-4, Doi: 10.1007/BF00776404.

[13] Rahmi., Lelifajri., Julinawati., Shabrina., (2017). Preparation of chitosan composite film reinforced with cellulose isolated from oil palm empty fruit bunch and application in cadmium ions removal from aqueous solutions. Carbohydrate Polymers 170: 226-33, Doi: 10.1016/j.carbpol.2017.04.084.

[14] El Boustani, M., Lebrun, G., Brouillette, F., Belfkira, A., (2017). Effect of a solvent-free acetylation treatment on reinforcements permeability and tensile behaviour of flax/epoxy and flax/wood fibre/epoxy composites. The Canadian Journal of Chemical Engineering 95(6): 1082-92, Doi: 10.1002/cjce.22777

[15] Loiacono, S., Crini, G., Martel, B., Chanet, G., Cosentino, C., Raschetti, M., et al., (2017). Simultaneous removal of $\mathrm{Cd}, \mathrm{Co}, \mathrm{Cu}, \mathrm{Mn}, \mathrm{Ni}$, and $\mathrm{Zn}$ from synthetic solutions on a hemp-based felt. II. Chemical modification. Journal of Applied Polymer Science 134(32): 45138, Doi: 10.1002/ app. 45138

[16] Li, X., Tabil, L.G., Panigrahi, S., (2007). Chemical Treatments of Natural Fiber for Use in Natural Fiber-Reinforced Composites: A Review. Journal of Polymers and the Environment 15(1): 25-33, Doi: 10.1007/s10924006-0042-3. 
[17] Luo, X., Benson, R.S., Kit, K.M., Dever, M., (2002). Kudzu fiber-reinforced polypropylene composite. Journal of Applied Polymer Science 85(9): 1961-9, Doi: 10.1002/app.10762.

[18] Bacci, L., Baronti, S., Predieri, S., di Virgilio, N., (2009). Fiber yield and quality of fiber nettle (Urtica dioica L.) cultivated in Italy. Industrial Crops and Products 29(2-3): 480-4, Doi: 10.1016/j.indcrop.2008.09.005.

[19] Angelini, L.G., Scalabrelli, M., Tavarini, S., Cinelli, P., Anguillesi, I., Lazzeri, A., (2015). Ramie fibers in a comparison between chemical and microbiological retting proposed for application in biocomposites. Industrial Crops and Products 75: 178-84, Doi: 10.1016/j.indcrop.2015.05.004.

[20] Methacanon, P., Weerawatsophon, U., Sumransin, N., Prahsarn, C., Bergado, D.T., (2010). Properties and potential application of the selected natural fibers as limited life geotextiles. Carbohydrate Polymers 82(4): 1090-6, Doi: 10.1016/j.carbpol.2010.06.036.

[21] Sun, R., M. Fang, J., Goodwin, A., M. Lawther, J., J. Bolton, A., (1998). Fractionation and characterization of polysaccharides from abaca fibre. Carbohydrate Polymers 37(4): 351-9, Doi: 10.1016/\$0144-8617(98)00046-0.

[22] Fuqua, M.A., Huo, S., Ulven, C.A., (2012). Natural Fiber Reinforced Composites. Polymer Reviews 52(3): 259-320, Doi: $10.1080 / 15583724.2012 .705409$

[23] Devireddy, S.B.R., Biswas, S., (2017). Physical and mechanical behavior of unidirectional banana/jute fiber reinforced epoxy based hybrid composites. Polymer Composites 38(7): 1396-403, Doi: 10.1002/pc.23706.

[24] Aguilar-Rios, A., Herrera-Franco, P.J., Martinez-Gomez, A. de J., Valadez-Gonzalez, A., (2014). Improving the bonding between henequen fibers and high density polyethylene using atmospheric pressure ethylene-plasma treatments. Express Polymer Letters 8(7): 491-504, Doi: 10.3144/expresspolymlett.2014.53.

[25] Reddy, N., Yang, Y., (2005). Biofibers from agricultural byproducts for industrial applications. Trends in Biotechnology, 23(1): 22-27, Doi: 10.1016/j.tibtech.2004.11.002

[26] Ramakrishna, G., Sundararajan, T., (2005). Studies on the durability of natural fibres and the effect of corroded fibres on the strength of mortar. Cement and Concrete Composites 27(5): 575-82, Doi: 10.1016/j. cemconcomp.2004.09.008

[27] Malkapuram, R., Kumar, V., Yuvraj Singh Negi., (2009). Recent Development in Natural Fiber Reinforced Polypropylene Composites. Journal of Reinforced Plastics and Composites 28(10): 1169-89, Doi: $10.1177 / 0731684407087759$.

[28] Azwa, Z.N., Yousif, B.F., Manalo, A.C., Karunasena, W., (2013). A review on the degradability of polymeric composites based on natural fibres. Materials \& Design 47: 424-42, Doi: 10.1016/j.matdes.2012.11.025.

[29] Parameswaran, B., Sugarcane Bagasse. (2009). In: Singh nee' Nigam P. Pandey A. (eds) Biotechnology for Agro-Industrial Residues Utilisation. Springer, Dordrecht. 239-240.

[30] Khan, Z., Yousif, B.F., Islam, M., (2017). Fracture behaviour of bamboo fiber reinforced epoxy composites. Composites Part B: Engineering 116: 186-99, Doi: 10.1016/j.compositesb.2017.02.015.

[31] Kumar, N., Mireja, S., Khandelwal, V., Arun, B., Manik, G., (2017). Light-weight high-strength hollow glass microspheres and bamboo fiber based hybrid polypropylene composite: A strength analysis and morphological study. Composites Part B: Engineering 109: 277-85, Doi: 10.1016/j.compositesb.2016.10.052.

[32] Yin, Q.F., et al., (2012). Preparation and Properties of Lignin-Epoxy Resin Composite. Bioresources, 7(4): 5737-5748. Doi: 10.15376/biores.7.4.5737-5748

[33] La Mantia, F.P., Morreale, M., (2011). Green composites: A brief review. Composites Part A: Applied Science and Manufacturing 42(6): 579-88, Doi: 10.1016/j.compositesa.2011.01.017.
[34] Wang, W., Huang, G., (2009). Characterisation and utilization of natural coconut fibres composites. Materials \& Design 30(7): 2741-4, Doi: 10.1016/j.matdes.2008.11.002

[35] Kapok. (2017) [cited 2017 03.10.2017]; Available from: https://www. britannica.com/topic/kapok.

[36] Chun, K.S., Husseinsyah, S., Yeng, C.M., (2016). Green composites from kapok husk and recycled polypropylene. Journal of Thermoplastic Composite Materials 29(11): 1517-35, Doi: 10.1177/0892705715569822.

[37] Daud, W.R.W. and K.N. Law, (2011) Oil Palm Fibers as Papermaking Material: Potentials and Challenges. Bioresources, 6(1): 901-917.

[38] Jute (Corchorus capsularis \& C. olitorius). (2017) 03.10.2017].

[39] Zakriya, M., Ramakrishnan, G., Gobi, N., Palaniswamy, N., Srinivasan, J., (2017). Jute-reinforced non-woven composites as a thermal insulator and sound absorber - A review. Journal of Reinforced Plastics and Composites 36(3): 206-13, Doi: 10.1177/0731684416679745.

[40] Yan, L., Chouw, N., Jayaraman, K., (2014). Flax fibre and its composites - A review. Composites Part B: Engineering 56: 296-317, Doi: 10.1016/j. compositesb.2013.08.014.

[41] Shahzad, A., (2012). Hemp fiber and its composites - a review. Journal of Composite Materials 46(8): 973-86, Doi: 10.1177/0021998311413623.

[42] Hafizah, N.A.K., Bhutta, M.A.R., Jamaludin, M.Y., Warid, M.H., Ismail, M., Rahman, M.S., et al., (2014). Kenaf Fiber Reinforced Polymer Composites for Strengthening RC Beams. Journal of Advanced Concrete Technology 12(6): 167-77, Doi: 10.3151/jact.12.167.

[43] Yu, H., Yu, C., (2007). Study on microbe retting of kenaf fiber. Enzyme and Microbial Technology 40(7): 1806-9, Doi: 10.1016/j.enzmictec.2007.02.018

[44] Liu, X. and L. Cheng, (2017). Influence of plasma treatment on properties of ramie fiber and the reinforced composites. Journal of Adhesion Science and Technology, 31(15): 1723-1734

[45] Nadlene, R., Sapuan, S.M., Jawaid, M., Ishak, M.R., Yusriah, L., (2016). A Review on Roselle Fiber and Its Composites. Journal of Natural Fibers 13(1): 10-41, Doi: 10.1080/15440478.2014.984052.

[46] Malenab, R., Ngo, J., Promentilla, M., (2017). Chemical Treatment of Waste Abaca for Natural Fiber-Reinforced Geopolymer Composite. Materials 10(6): 579, Doi: 10.3390/ma10060579.

[47] Sathish, P., Kesavan, R., Ramnath, B.V., Vishal, C., (2017). Effect of Fiber Orientation and Stacking Sequence on Mechanical and Thermal Characteristics of Banana-Kenaf Hybrid Epoxy Composite. Silicon 9(4): 577-85, Doi: 10.1007/s12633-015-9314-7.

[48] Badgujar, A.G., Bambole, V.A., Mahanwar, P.A., (2011). Preparation and Characterization of Polypyrrole-Modified Henequen Fiber-Reinforced Polymethylmethacrylate Composites. Polymer-Plastics Technology and Engineering 50(12): 1281-7, Doi: 10.1080/03602559.2011.584241.

[49] Ibrahim, I.D., Jamiru, T., Sadiku, R.E., Kupolati, W.K., Agwuncha, S.C., (2017). Dependency of the Mechanical Properties of Sisal Fiber Reinforced Recycled Polypropylene Composites on Fiber Surface Treatment, Fiber Content and Nanoclay. Journal of Polymers and the Environment 25(2): 427-34, Doi: 10.1007/s10924-016-0823-2

[50] Adeel, S., et al., (2016). Bio-Processing of Surface-Oxidised Cellulosic Fibre by Microwave Treatment for Eco-Friendly Textile Dyeing. Oxidation Communications, 39(3): 2396-406.

[51] Ahmad, S.H., Rasid, R., Bonnia, N.N., Zainol, I., Mamun, A.A., Bledzki, A.K., et al., (2011). Polyester-Kenaf Composites: Effects of Alkali Fiber Treatment and Toughening of Matrix Using Liquid Natural Rubber. Journal of Composite Materials 45(2): 203-17, Doi: 10.1177/0021998310373514. 
[52] Ali, M.E., Sultana, Z., Uddin, M.S., Mamun, S.A., Haque, M.M., Hasan, M., (2013). Effect of hydrazine post-treatment on natural fibre reinforced polymer composites. Materials Research Innovations 17: 19-26, Doi: 10 $.1179 / 1432891713 Z .000000000295$

[53] Baltazar-y-Jimenez, A., Juntaro, J., Bismarck, A., (2008). Effect of Atmospheric Air Pressure Plasma Treatment on the Thermal Behaviour of Natural Fibres and Dynamical Mechanical Properties of Randomly-Oriented Short Fibre Composites. Journal of Biobased Materials and Bioenergy 2(3): 264-72, Doi: 10.1166/jbmb.2008.410.

[54] Bian, P., Dai, Y., Qian, X., Chen, W., Yu, H., Li, J., et al., (2014). A process of converting cellulosic fibers to a superhydrophobic fiber product by internal and surface applications of calcium carbonate in combination with bio-wax post-treatment. RSC Adv. 4(95): 52680-5, Doi: 10.1039/ C4RA08437C.

[55] Chandrasekar, M., Ishak, M.R., Sapuan, S.M., Leman, Z., Jawaid, M., (2017). A review on the characterisation of natural fibres and their composites after alkali treatment and water absorption. Plastics, Rubber and Composites 46(3): 119-36, Doi: 10.1080/14658011.2017.1298550.

[56] Cho, D., Seo, J.M., Lee, H.S., Cho, C.W., Han, S.O., Park, W.H., (2007). Property improvement of natural fiber-reinforced green composites by water treatment. Advanced Composite Materials 16(4): 299-314,

[57] Cisneros-López, E.O., González-López, M.E., Pérez-Fonseca, A.A., González-Núñez, R., Rodrigue, D., Robledo-Ortíz, J.R., (2017). Effect of fiber content and surface treatment on the mechanical properties of natural fiber composites produced by rotomolding. Composite Interfaces 24(1): 35-53, Doi: 10.1080/09276440.2016.1184556.

[58] Enciso, B., Abenojar, J., Martínez, M.A., (2017). Influence of plasma treatment on the adhesion between a polymeric matrix and natural fibres. Cellulose 24(4): 1791-801, Doi: 10.1007/s10570-017-1209-x.

[59] Fiore, V., Scalici, T., Nicoletti, F., Vitale, G., Prestipino, M., Valenza, A. (2016). A new eco-friendly chemical treatment of natural fibres: Effect of sodium bicarbonate on properties of sisal fibre and its epoxy composites. Composites Part B: Engineering 85: 150-60, Doi: 10.1016/j.compositesb.2015.09.028

[60] Fu, J.J., Z.W. Sun, and C.W. Yu, (2007). Research on one-bath alkali-H2O2 treatment for natural bamboo fiber degumming. Proceedings of the 2007 International Conference on Advanced Fibers and Polymer Materials 1(2): 727-729.

[61] Gulati, D. and M. Sain, (2005). Surface treatment of bio-fibres: A comparison between alkalization, acetylation and enzymatic treatment. Abstracts of Papers of the American Chemical Society 229: U296-U296.

[62] Holt, G.A., Chow, P., Wanjura, J.D., Pelletier, M.G., Wedegaertner, T.C., (2014). Evaluation of thermal treatments to improve physical and mechanical properties of bio-composites made from cotton byproducts and other agricultural fibers. Industrial Crops and Products 52: 627-32, Doi: 10.1016/j.indcrop.2013.11.003.

[63] Hossain, S.I., Hasan, M.N., Hasan, M.N., Hassan, A., (2013). Effect of Chemical Treatment on Physical, Mechanical and Thermal Properties of Ladies Finger Natural Fiber. Advances in Materials Science and Engineering 2013: 1-6, Doi: 10.1155/2013/824274.

[64] Islam, M., Beg, M., Mina, M., (2014). Fibre surface modifications through different treatments with the help of design expert software for natural fibre-based biocomposites. Journal of Composite Materials 48(15): 1887-99, Doi: 10.1177/0021998313491515.

[65] Janardhnan, S., Sain, M., (2011). Bio-Treatment of Natural Fibers in Isolation of Cellulose Nanofibres: Impact of Pre-Refining of Fibers on Bio-Treatment Efficiency and Nanofiber Yield. Journal of Polymers and the Environment 19(3): 615-21.
[66] Jayamani, E., Hamdan, S., Bakri, M.K. Bin., Kok Heng, S., Rahman, M.R., Kakar, A., (2016). Analysis of natural fiber polymer composites: Effects of alkaline treatment on sound absorption. Journal of Reinforced Plastics and Composites 35(9): 703-11.

[67] Jin, Z., Luo, Z., Yang, S., Lu, S., (2015). Influence of complexing treatment and epoxy resin coating on the properties of aramid fiber reinforced natural rubber. Journal of Applied Polymer Science 132(25), Doi: 10.1002/ app. 42122 .

[68] Khoshnava, S.M., Rostami, R., Ismail, M., Valipour, A., (2014). The Using Fungi Treatment as Green and Environmentally Process for Surface Modification of Natural Fibres. Applied Mechanics and Materials 554: 116-22, Doi: 10.4028/www.scientific.net/AMM.554.116.

[69] Kondo, Y., Miyazaki, K., Takayanagi, K., Sakurai, K., (2008). Surface treatment of PET fiber by EB-irradiation-induced graft polymerization and its effect on adhesion in natural rubber matrix. European Polymer Journal 44(5): 1567-76, Doi: 10.1016/j.eurpolymj.2008.02.020.

[70] Kord, B., (2013). Assessment of long-term water absorption in natural fiber reinforced thermoplastic composites influenced by filler rate and compatibilizer treatment. Journal of Thermoplastic Composite Materials 26(3): 296-306, Doi: 10.1177/0892705711423289.

[71] Koziol, M., Bogdan-Wlodek, A., Myalski, J., Wieczorek, J., (2011). Influence of wet chemistry treatment on the mechanical performance of natural fibres. Polish Journal of Chemical Technology 13(4): 21-27

[72] Kunanopparat, T., Menut, P., Morel, M.-H., Guilbert, S., (2008). Plasticized wheat gluten reinforcement with natural fibers: Effect of thermal treatment on the fiber/matrix adhesion. Composites Part A: Applied Science and Manufacturing 39(12): 1787-92.

[73] Li, W., Meng, L., Ma, R., (2016). Effect of surface treatment with potassium permanganate on ultra-high molecular weight polyethylene fiber reinforced natural rubber composites. Polymer Testing 55: 10-6, Doi: 10.1016/j.polymertesting.2016.08.006.

[74] Liu, L., Cheng, L., Huang, L., Yu, J., (2012). Enzymatic treatment of mechanochemical modified natural bamboo fibers. Fibers and Polymers 13(5): 600-5, Doi: 10.1007/s12221-012-0600-3.

[75] Liu, T., et al., (2013). Effect of Fiber Type and Coupling Treatment on Properties of High-Density Polyethylene/Natural Fiber Composites. Bioresources, 8(3): 4619-32.

[76] Lopattananon, N., Panawarangkul, K., Sahakaro, K., Ellis, B., (2006). Performance of pineapple leaf fiber-natural rubber composites: The effect of fiber surface treatments. Journal of Applied Polymer Science 102(2): 1974-84, Doi: 10.1002/app.24584

[77] Luciu, I., et al., (2008). Low and Atmospheric Pressure Plasma Treatment of Natural Textile Fibers. Isdeiv 2008: Proceedings of the Xxiiird International Symposium on Discharges and Electrical Insulation in Vacuum, Vols 1 and 2, 2008: 499-502

[78] Mishra, S., Naik, J.B., (2005). Effect of Treatment of Maleic Anhydride on Mechanical Properties of Natural Fiber: Polystyrene Composites. Polymer-Plastics Technology and Engineering 44(4): 663-75.

[79] Morshed, M.M., Alam, M.M., Daniels, S.M., (2010). Plasma Treatment of Natural Jute Fibre by RIE 80 plus Plasma Tool. Plasma Science and Technology 12(3): 325-9, Doi: 10.1088/1009-0630/12/3/16.

[80] Pickering, K.L., Sawpan, M.A., Jayaraman, J., Fernyhough, A., (2011). Influence of loading rate, alkali fibre treatment and crystallinity on fracture toughness of random short hemp fibre reinforced polylactide bio-composites. Composites Part A: Applied Science and Manufacturing 42(9): 1148-56, Doi: 10.1016/j.compositesa.2011.04.020.

[81] Reich, S., ElSabbagh, A., Steuernagel, L., (2008). Improvement of Fibre-Matrix-Adhesion of Natural Fibres by Chemical Treatment. Macromolecular Symposia 262(1): 170-81. 
[82] Rokbi, M., et al., (2011). Effect of Chemical treatment on Flexure Properties of Natural Fiber-reinforced Polyester Composite. 11th International Conference on the Mechanical Behavior of Materials (Icm11), 10.

[83] Scalici, T., Fiore, V., Valenza, A., (2016). Effect of plasma treatment on the properties of Arundo Donax L. leaf fibres and its bio-based epoxy composites: A preliminary study. Composites Part B: Engineering 94: 167-75, Doi: 10.1016/..compositesb.2016.03.053.

[84] Shah, D.U., Schubel, P.J., Licence, P., Clifford, M.J., (2012). HydroxyethyIcellulose surface treatment of natural fibres: the new 'twist' in yarn preparation and optimization for composites applicability. Journal of Materials Science 47(6): 2700-11.

[85] Sirvaitiene, A., et al., (2013). Influence of Natural Fibre Treatment on Interfacial Adhesion in Biocomposites. Fibres \& Textiles in Eastern Europe, 21(4): 123-29.

[86] Sotenko, M., Coles, S.R., McEwen, I., DeCampos, R., Barker, G., Kirwan, K., (2016). Biodegradation as natural fibre pre-treatment in composite manufacturing. Green Materials 4(1): 8-17.

[87] Stocchi, A., Bernal, C., Vázquez, A., Biagotti, J., Kenny, J., (2007). A Silicone Treatment Compared to Traditional Natural Fiber Treatments: Effect on the Mechanical and Viscoelastic Properties of Jute-Vinylester Laminates. Journal of Composite Materials 41(16): 2005-24.

[88] Suradi, S.S., R.M. Yunus, Beg, M.D.H. (2011). Oil palm bio-fiber-reinforced polypropylene composites: effects of alkali fiber treatment and coupling agents. Journal of Composite Materials 45(18): 1853-61.

[89] Tan, H.S., et al., (2011). Effect of Alkali Treatment of Coir Fiber on Its Morphology and Performance of the Fiber/LLDPE Bio-composites. Manufacturing Engineering and Automation I, Pts 1-3, 139-141: p. 348.

[90] Tan, S.J., Supri, A.G., (2016). Properties of low-density polyethylene/ natural rubber/water hyacinth fiber composites: the effect of alkaline treatment. Polymer Bulletin 73(2): 539-57, Doi: 10.1007/s00289-0151508-z.

[91] Tserki, V., Zafeiropoulos, N.E., Simon, F., Panayiotou, C., (2005). A study of the effect of acetylation and propionylation surface treatments on natural fibres. Composites Part A: Applied Science and Manufacturing 36(8): $1110-18$

[92] Valadez-Gonzalez, a., Cervantes-Uc, J.M., Olayo, R., Herrera-Franco, P.J (1999). Effect of fiber surface treatment on the fiber-matrix bond strength of natural fiber reinforced composites. Composites Part B: Engineering 30(3): 309-20, Doi: 10.1016/S1359-8368(98)00054-7.

[93] Yan, L., Chouw, N., Yuan, X., (2012). Improving the mechanical properties of natural fibre fabric reinforced epoxy composites by alkali treatment. Journal of Reinforced Plastics and Composites 31(6): 425-37, Doi: $10.1177 / 0731684412439494$.

[94] Zaborski, M., Lipinska, M.P., (2003). The effect of enzyme and plasma treatments of fibers on their adhesion to natural rubber. Przemysl Chemiczny. 82(8-9): 985-988.

[95] Verma, D., Jain, S., (2017). Effect of Natural Fibers Surface Treatment and their Reinforcement in Thermo-Plastic Polymer Composites: A Review. Current Organic Synthesis, 14(2): 186-199

[96] Albinante, S.R., E.B.A.V. Pacheco, Visconte, L.L.Y. (2013). A Review on Chemical Treatment of Natural Fiber for Mixing with Polyolefins. Quimica Nova, 36(1): p. 114-122.

[97] Irina, K.C., G. Stanciu, Gutaga, S. (2004). The treatment of natural fibers used in composite materials. Bulletin of the University of Agricultural Sciences and Veterinary Medicine, 61: 473-473.

[98] Ahmad, I., A. Baharum, Abdullah, I. (2006). Effect of extrusion rate and fiber loading on mechanical properties of twaron fiber-thermoplastic natural rubber (TPNR) composites. Journal of Reinforced Plastics and Composites, 25(9): 957-65
[99] Hargitai, H., Rácz, I., Anandjiwala, R.D., (2008). Development of HEMP Fiber Reinforced Polypropylene Composites. Journal of Thermoplastic Composite Materials 21(2): 165-74, Doi: 10.1177/0892705707083949.

[100] Holbery, J., Houston, D., (2006). Natural-fiber-reinforced polymer composites applications in automotive. Jom, 58(11): 80-86.

[101] John, M.J., Anandjiwala, R.D., (2008). Recent developments in chemical modification and characterization of natural fiber-reinforced composites. Polymer Composites 29(2): 187-207, Doi: 10.1002/pc.20461.

[102] Ku, H., Wang, H., Pattarachaiyakoop, N., Trada, M., (2011). A review on the tensile properties of natural fiber reinforced polymer composites. Composites Part B: Engineering 42(4): 856-73, Doi: 10.1016/j.compositesb.2011.01.010.

[103] Mohammed, L., Ansari, M.N.M., Pua, G., Jawaid, M., Islam, M.S., (2015). A Review on Natural Fiber Reinforced Polymer Composite and Its Applications. International Journal of Polymer Science 2015: 1-15, Doi: 10.1155/2015/243947

[104] Saheb, D.N. and J.P. Jog, (1999). Natural fiber polymer composites: A review. Advances in Polymer Technology, 18(4): 351-363.

[105] Balaji, A., Karthikeyan, B., Swaminathan, J., Sundar Raj, C., (2017). Mechanical behavior of short bagasse fiber reinforced cardanol-formaldehyde composites. Fibers and Polymers 18(6): 1193-9, Doi: 10.1007/s12221017-7009-y

[106] Ninomiya, K., Abe, M., Tsukegi, T., Kuroda, K., Omichi, M., Takada, K., et al., (2017). Ionic liquid pretreatment of bagasse improves mechanical property of bagasse/polypropylene composites. Industrial Crops and Products 109: 158-62, Doi: 10.1016/j.indcrop.2017.08.019.

[107] Motaung, T., Mochane, M., Makhetha, T., Motloung, S., Mokhothu, T., Mokhena, T., et al., (2017). Effect of mechanical treatment on morphology and thermal and mechanical properties of sugar cane bagasse-low-density polyethylene composites. Polymer Composites 38(8): 1497-503, Doi: 10.1002/pc.23717.

[108] Chunhong, W., Shengkai, L., Zhanglong, Y., (2016). Mechanical, hygrothermal ageing and moisture absorption properties of bamboo fibers reinforced with polypropylene composites. Journal of Reinforced Plastics and Composites 35(13): 1062-74

[109] Luo, H.L., et al., (2016). Effects of Alkali and Alkali/Silane Treatments of Corn Fibers on Mechanical and Thermal Properties of Its Composites With Polylactic Acid. Polymer Composites, 37(12): 3499-507.

[110] Prachayawarakorn, J., Chaiwatyothin, S., Mueangta, S., Hanchana, A., (2013). Effect of jute and kapok fibers on properties of thermoplastic cassava starch composites. Materials \& Design 47: 309-15, Doi: 10.1016/..matdes.2012.12.012

[111] Dogan, S.D., Tayfun, U., Dogan, M.. (2016). New route for modifying cellulosic fibres with fatty acids and its application to polyethylene/jute fibre composites. Journal of Composite Materials, 50(18): 2477-2485.

[112] Oksman, K., M. Skrifvars, Selin, J.F. (2003).Natural fibres as reinforcement in polylactic acid (PLA) composites. Composites Science and Technology, 63(9): 1317-24.

[113] Anuar, H., et al., (2012). Improvement of Mechanical Properties of Injection-Molded Polylactic Acid-Kenaf Fiber Biocomposite. Journal of Thermoplastic Composite Materials, 25(2): 153-164.

[114] Campos, A., et al., (2012). Morphological, mechanical properties and biodegradability of biocomposite thermoplastic starch and polycaprolactone reinforced with sisal fibers. Journal of Reinforced Plastics and Composites, 31(8): 573-81.

[115] Koyuncu, M., Karahan, M., Karahan, N., Shaker, K., Nawab, Y., (2016). Static and Dynamic Mechanical Properties of Cotton/Epoxy Green Composites. Fibres and Textiles in Eastern Europe 24(4(118)): 105-11. 